\title{
Content Characteristics of Independent Work of Students (IWS): Modern Conditions and Problems
}

\author{
Ruzimurot Kungratovich Choriev', Ravshan Khudayarovich Usarov ${ }^{2}$, \\ Mohira Aminkulovna Sattorova ${ }^{3}$,Navruz Erkinovich Abdiev ${ }^{4}$, \\ Nozima Ravshanovna Pulatova ${ }^{5}$
}

\footnotetext{
${ }^{1}$ Acting Professor, Doctor of Pedagogical Sciences (DSc), Tashkent Institute of Irrigation and Agricultural Mechanization Engineers, Tashkent, Uzbekistan,

${ }^{2}$ Teacher, Termez branch of Tashkent State Pedagogical University named after Nizami, Termez, Uzbekistan,

${ }^{3}$ Teacher, Karshi State University, Karshi, Uzbekistan,

${ }^{4}$ Teacher, Tashkent Institute of Irrigation and Agricultural Mechanization Engineers, Tashkent, Uzbekistan,

${ }^{5}$ base doctoral student, A. Avloni Institute of Retraining and Advanced Training of Managers and Specialists of the Public Education System, Tashkent, Uzbekistan
}

\begin{abstract}
The article discusses the problem of organizing independent work under the guidance of a teacher, which can be considered effective only if the educational process is organized as a holistic system in each classroom and in extracurricular activities of students. However, these types of work can be partially interconnected with each other, and several types of classroom training on credit training technology have different goals, each of which has its own goal and is an ideal opportunity to perform the above training tasks. The work of independent students under the guidance of a teacher (IWS) focuses on classroom activities. At the same time, the analysis of normative documents and scientific and methodological literature, the description (IWS) are presented in the same sense in different sources, but nevertheless the main aspects of this concept are defined, and (IWS) is a joint training of students and teachers . type of activity (type of training), which is one of the aspects of ensuring the individual work of the student based on the installation, configuration and control of the teacher.
\end{abstract}

Key words: independent work of a student under the guidance of a teacher (IWS) critical technology, classroom activity, focus, classroom and extracurricular activities, activities.

Article Received: 16th October, 2020; Article Revised: 30th December, 2020; Article Accepted: 08th January, 2021

\section{I.Introduction.}

The goal of higher professional education is the formation of a creative personality of a specialist, capable of self-development, self-education, entrepreneurial and innovative activities. An important role in achieving this goal belongs to independent work. The main task of the students' independent work is mastering fundamental knowledge, professional skills and skills, in the field of creative, research activities. Independent work (hereinafter IWS ) is the form, method, means and condition for the development of cognitive activity of a future specialist. Its equipping tasks are realized through the organization of educational and research activities of students, carried out during extracurricular hours on the instructions and with the methodological guidance of the teacher, but without his direct participation. Such activity can be considered effective only when the educational process is organized as an integrated system, when each type of student's classroom and extracurricular work will have its own focus, but at the same time, these types of work will partially interact with each other. In the credit technology of teaching, several types of classroom activities are presented, each of which has its own purposefulness, and it is this type of classroom activity as an independent student work under the guidance of a teacher (IWS) that is essentially an ideal opportunity to carry out the above pedagogical task. An analysis of normative documents and scientific and methodological literature indicates that the definition of IWS is presented in different sources 
ambiguously, but nevertheless, the main facets of this concept can be distinguished. IWST - a type of educational activity (type of training session) performed by students and the teacher together, which provides for the individual work of the student in accordance with the installation, correction and control of the teacher [Ismailova Z., et al. 2018].

If there are two types of classes in credit technology for teaching directly aimed at students' independent activity, it is important to note the main difference between the student's independent work (IWS) and IWST: IWS is controlled by the teacher indirectly through special teaching materials, while IWW is a process of continuous direct interaction two sides of the learning process. IWS, being one of the types of classroom studies on credit technology of training, has a number of meaningful characteristics. The defining characteristic of SRSP are the functions that must be performed during this lesson.

So, in the book "Credit system of education: implementation experience and prospects", Myrzaliev B.A., Makhashov E.Zh., Nurashev K.K. and others. It is indicated that IWS has two functions: supervising and advising, which makes it possible to determine the main focus of this type of occupation, namely: consultation in planning and control in the implementation of students' independent activities by the teacher [Myrzaliev B.A., et al. 2017. P. 135]. The student must learn to determine the goal, highlight cognitive tasks, perform independent control over the correctness of the tasks, improve the skill of self-adjustment in the process of activity and introspection when the result is achieved. Conventionally, this target orientation of IWC can be divided into two vectors: a clear understanding of goals, objectives, forms and methods of work, and the formation of habits based on mechanical repetitions of a particular type of activity in the lesson. IWC takes the form of business interaction: the student receives direct instructions, recommendations of the teacher on the organization of independent activity, and the teacher performs the management function through accounting, control and correction of erroneous actions directly, in the educational process.

Also, the type of classroom activity we are considering is distinguished by the specificity of the motivational component. The analysis of the literature made it possible to propose a number of factors that contribute to the activation of the student's activity in the class of IWS. So, the first factor is the usefulness of the work performed by the student. Usefulness can consist both in the individual development of the student's personality, in the development of his intellectual orientation, and in the student's involvement in the academic life of the university (preparation of publications, participation in competitions, conferences, scientific competitions of projects, etc.).

II. THE MAIN PART. Another motivating factor may be the use of the results of educational activities in vocational training or in further professional activities. Performing a task independently under the supervision of a teacher, a student unconsciously automates the skill of setting a goal and setting goals for achieving it — which will be a necessity in the student's further professional activity. Also, intensive pedagogy is an equally important factor in the motivational aspect of IWS, where the teacher's task is to make the learning process fascinating and interesting for students through the use of active teaching methods. Also, in addition to the factors presented above, such factors as encouraging students, individualization of tasks, creative orientation, etc. can be distinguished.

The organization of IWS is characterized by versatility and phasing. Presumably, the organization of the IWS should proceed in two stages:

The first stage is the period of the initial 
organization, requiring the teacher to directly participate in the activities of students, with the detection and indication of the causes of errors.

The second stage is the period of selforganization, when the direct participation of the teacher in the process of independent formation of student knowledge is no longer required.

In the organization of the IWC, it is important to pay attention to the structure, volume and content of the educational material, since the students' activities are more independent, despite the control and adjustment by the teacher. An important role is played by the methodological support of the IWC, since the various methodological manuals and recommendations on independent work of students now being used are usually informational in nature. The student, however, must be oriented toward creative activity in the context of discipline.

Consider the types of independent work in the context of student-teacher collaboration, with which you can construct a conditional model of tasks in the organization of SRSPThe first type of independent work includes the formation of the skills of students to identify externally what is required of them, based on the algorithm of activity given to them and the premises for this activity contained in the condition of the assignment. The cognitive activity of the trainees in this case consists in recognizing objects of a given field of knowledge during the repeated perception of information about them or actions with them.

Three levels of independent work can be distinguished: reproductive, productive, and creative. For the assimilation of new knowledge, deepening and repetition, previously acquired knowledge of their generalization and systematization at each of the selected levels, various forms of independent work are provided.

The 1st level should include such types of work as the perception of educational information from various sources, the preparation of a textual summary, reproductive reproduction of knowledge.

2 nd level requires the ability to prepare a free summary based on the student's comprehension of the material studied, to draw up a plan for a book (article) read, to compile a bibliographic list to accumulate scientific information in the form of extracts and citations, etc.

At the 3rd level, the tasks become more complicated: preparation of essays, reviews, references, abstracts, reports, handouts, peer-reviewed scientific and educational literature, etc. During the collection and analysis of information during course and diploma research, skills and attitudes to establish completeness and reliability will be required. , accessibility, consistency, evidence of material from various sources, identifying factors affecting a particular social phenomenon, process, event.

III. DISCUSSION. Independence is the ability to focus on one's personal positions, make one's own decisions and realize them, and one's independence from situational external influences [Еникеев М.И. 2006. p. 404].

Independent work of students (IWS) is an informative, informative, organizationally and methodically directing activity carried out without the direct assistance of a teacher to achieve a specific result. IWC is the diverse types of individual and collective activities of students, carried out under the guidance, but without the direct participation of the teacher, and specially allocated for this classroom or nonauditory time. This is a special form of training according to the instructions of the teacher.

In accordance with the requirements of standards, all types of activities of an educational organization in relation to quality are "quality assurance in education". The decomposition of this activity in relation to the IWC can be represented by the following areas [Федоров В.А. 1999.pp..189-198]:

- quality planning, that is, activities aimed 
at forming a strategy, policy and related goals and requirements for the quality of the IWC;

- quality management, that is, the application of certain methods and activities of an operational nature used to fulfill the quality requirements of the IWC; - improving the quality, that is, the inclusion of such types of activities that ensure compliance with the requirements for improving the quality of the educational organization, while the requirements may relate to any aspect of this activity: effectiveness, efficiency, traceability, etc.

- quality assessment, that is, the inclusion of diagnostic procedures for evaluating the IWC, which are aimed at confirming that the quality requirements for this type of educational activity are fulfilled. Thus, the IWC, as the most important type of educational activity, has various types and forms [Ismailova Z.K, et al.2018].

As an independent work of this type, work with a textbook is most often used. An example of such tasks is the work with the text and the tasks attached to it, aimed at developing critical thinking of students. The second type of independent work is the formation of knowledge-copies and knowledge, allowing to solve typical problems.

The cognitive activity of the trainees in this case consists in the pure reproduction and partial reconstruction, transformation of the structure and content of the previously learned educational information, which implies the need to analyze this description of the object, various ways of completing the task, choosing the most correct of them, or sequentially determining logically successive solutions An example of such work is the analysis of the text with the subsequent construction of its own (the text can be either written or oral). The third type of independent work is the formation of the knowledge of the students that underlie the solution of atypical problems.
The cognitive activity of trainees in solving such problems consists in the accumulation and manifestation in the external plan of a new activity experience for them on the basis of previously acquired formalized experience (actions according to a well-known algorithm) by transferring knowledge, skills and abilities. Tasks of this type involve the search, formulation and implementation of the idea of a solution, which always goes beyond the limits of past formalized experience and requires the student to vary the conditions of the task and previously learned educational information, consider them from a new angle. An example of such tasks in the IWST lesson is a report where students, based on existing theoretical knowledge, present their own opinions and offer their own solutions to existing problems. Creative activity is the fourth type of independent work.

IV.CONCLUCIONS. The cognitive activity of trainees in carrying out these works consists in deeply penetrating into the essence of the object being studied, establishing new connections and relationships necessary to find new, previously unknown principles, ideas, and generate new information. This type of independent work is realized when performing tasks of a creative nature: an essay, a scientific project, etc. The main concept in the organization of this type of work is the critical thinking of students, which helps to analyze things and events with the formulation of sound conclusions, which allows us to evaluate, interpret, and correctly apply the results to situations and problems.

Based on the foregoing, it can be concluded that IWST, as a type of classroom activity, has a number of characteristics, such as purposefulness, functions, phased organization in accordance with the objectives of this type of activity, and presentation of activities aimed at increasing the level of students' cognitive independence. These factors 
serve as the basis for identifying IWST as a separate type of classroom activities, emphasizing the importance of the student's independent activity as an integral part of the paradigm of modern education.

\section{REFERENCES:}

[1] The state program for the development of education and science of the Republic of Kazakhstan for 2016 - 2019. 2016. Astana: Official publication, 2016. $23 \mathrm{p}$.

[2] Rubinstein S. L. Fundamentals of General Psychology. - St. Petersburg, $2001 .--720$ p.

[3] Platonov K.K., Golubev G.G. Psychology - M : Higher School, 1973. - $256 \mathrm{p}$.

[4] Pedagogical encyclopedic dictionary. - M., 2002. 479 p.

[5] Myrzaliev B.A., Makhashov E.Zh., Nurashev K.K. et al. Credit training system: implementation experience, problems and prospects. Un Journal of Scientific and Applied Research • No 3/2017.-259 p.

[6] Fedorov V.A. The quality of vocational and pedagogical education / Fedorov // Education and Science.1999 .-? 2 (2). pp..189-198.

[7] Enikeev M.I. Psychological Encyclopedic Dictionary / M.I. EnikeevM.: TK Velbi, Prospect Publishing House, 2006.-560 p.

[8] Ismailova Z.K, Khimmataliev D.A, Fayzullaev R.H. Methodical instructions on implementation of course project on "Methods of vocational education", SIQMI, 2018. - $27 \mathrm{p}$.

[9] Ismailova Z., Khimmataliev D.A., Baybaeva M.H., Fayzullaev R.H. "Explanatory dictionary on general professional subjects" Tashkent, Uzbekistan, 2018. - 85 p.

[10] Ismailova, Z. K., Khimmataliev, D. O., Khashimova, M. K., Baybaeva,
M. K., \& Ergashev, B. B. (2020). Integrative approach to designing the content of secondary specialized vocational education. Opcion, 36(91), 25-41.

[11] Ismailova, Z., Choriev, R., Musurmanova, A., \& Aripjanova, M. (2020). Methods of training of teachers of university on advanced training courses. Journal of Critical Reviews. Innovare Academics Sciences Pvt. Ltd. https://doi.org/10.31838/jcr.07.05.85

[12] Ismailova, Z., Choriev, R., Salomova, R., \& Jumanazarova, Z. (2020). Use of economic and geographical methods of agricultural development. Journal of Critical Reviews. Innovare Academics Sciences Pvt. Ltd. https://doi.org/10.31838/jcr.07.05.84

[13] Ruzimurat Kungratovich Choriev, Muhabbat Fayzievna Khakimova, Oybek Olimovich Daminov, Hasan Ravshanovich Gaffarov, Khayrullo Ergashovich Tuychiev, Nurilla Normirza-o'g'li Makhmudov. // Mechanisms of professional competence development for future teachersю

[14] Choriyev R.K. Pedagogical technologies in dual training model // European Journal of Research and Reflection in Educational Sciences Vol. 8 № 1, 2020. ISSN 2056-5852. P. 3-66.

[15] Choriyev R.K. Formation of professional competencies of hightech

industry specialists in dual education.// European Journal of Research and Reflection in Educational Sciences. Volume 8 Number 4, 2020 Part II ISSN 2056-5852. - P. 112-114.

[16] Choriyev R.K. Pedagogical technologies in dual training model. //

European Journal of Research and Reflection in Educational Sciences, 8 
(1)

2020,

- P. 63-66. (13.00.00; № 3)

[17] Zukhra Ismailova, Shirinboy Olimov, Durdona Mustafoeva, Yulduz Yarmanova, Nargiza Temirkulova. (2020). Technology Of Diagnostic Level Of Development Of Professional Competence Of Pedagogical Personnel In The System Of Training. International Journal of Advanced Science and Technology, 29(7), 3337-3343. Retrieved from

[18]

http://sersc.org/journals/index.php/IJ AST/article/view/21886

[19] Zukhra Ismailova, Olim Turakulov, Shakhnoz Samieva, Igamberdi Tufliev, Abdakim Mamataliev. (2020). Technology, Content, Form And Methods Of Independent Work Of Students In Modern Conditions. International Journal of Advanced Science and Technology,29(7), 33443348. Retrieved from

[20]

http://sersc.org/journals/index.php/IJ AST/article/view/21887

[21] Khimmataliev D., Khakimov J., Daminov O., Rakhmatova F. Criteria and indicators for assessing the level of professional training of future teachers of vocational training at a training module // Journal of critical reviews. ISSN - 2394-5125. Vol 7, Issue 5, 2020 - p. 428-431. doi: $10.31838 /$ jcr.07.05.89

[22] Khimmataliev D.O. Integration of pedagogical and technical knowledge in the diagnosis of preparation for professional activity. Monograph. Tashkent, Uzbekistan, 2018 - 168 p.

[23] 21. Khimmataliev D.O. Integration of pedagogical and technical knowledge in the diagnosis of professional training: Doctorate in Pedagogical Sciences (DSc) diss. avtoref. - T .: 2018. -70 b 120

[24] Khimmataliev D.O. Integration of scientific knowledge in preparation for the professional activities of future teachers of vocational education // School of the future. Moscow, 2016. No. 6. -S. 50-54.

[25] Olimov K. T. et al. Competent training of future specialists on the basis of acmelogical approach //Journal of Critical Reviews. - 2020. - T. 7. - №. 15. - P. 2476-2483.

[26] Olimov K. T et al..Introduction of dual training in the system of continuous professional education. European Journal of Research and Reflection in Educational Sciences// -2020. Volume 7 Number 12, 2019 Part VI. P. 509-512

[27] Olimov K. T. et al. Teaching Special Subjects for Students with Disabilities in Preparation for the Profession by Using Innovative Educational Technologies //International Journal of Innovative Technology and Exploring Engineering (IJITEE). - 2019. - T. 9. - C. 425-429.

[28] August 2017 www.interfinance.uz.8. Shaykhov's A.E. under general edit. Franchising Guide for Entrepreneurs of Uzbekistan Methodical Guide. Tashkent, 2008 Pages 4-11. Website: www.chamber.uz, www.bfu.uz.

[29] Ismailova Z. Et al. The use of innovation technologies in the formation of students' professional competences. International joburnal of ingenering and advanced technology (tm) Volume-9 lssue-1. October.2019.1175 p. 